\title{
The Effectiveness of Match Technique to Improve Students' Vocabulary Mastery based on Gender
}

\author{
Via Destika ${ }^{1}$ \\ ${ }^{1}$ Lampung University, Indonesia. \\ 凶email: via.destika@yahoo.com
}

\section{Received: \\ 01 December 2021 \\ Revised: \\ 02 December 2021

Accepted:
02 January 2022
Published:
02 January 2022

\begin{abstract}
This research that belongs to quantitative research aims at finding the effectiveness of make a match technique to improve students' vocabulary based on gender. The instrument given to the students was vocabulary in the context of a descriptive text. The subject of this research consisted of 25 students. This research only used experimental class for this research. The result of this research, there were significant improvement between pre-test and post-test score. The result obtained from sample T-test, it was found that the $p$ value $(0,000)$ was lower than 0.05 and t-observed (25.296) was higher than t-table (2.064). While the result of differences score between female and male based on post test, the $\mathrm{p}$ value (.859) was higher than 0.05 , there were not significant differences of vocabulary score between female and male. So, this technique make students interesting in teaching and learning vocabulary, this technique also helps students to understand about material easily.
\end{abstract}

Keywords: Vocabulary; Teaching Method; Mtach Techniqu; Descriptive Text; Gender Strategy.

\section{INTRODUCTION}

Vocabulary is a component of English. Without vocabulary mastery it is impossible to make meaningful sentences in communication. Vocabulary is a list of words. Kamil and Hiebert (2005) state that vocabulary is the knowledge of meanings of words. Celce-Murcia \& Ohlstain (2000) declared that the vocabulary is a key of language, because without vocabulary the language cannot be conveyed. And Stahl (2005) has stated that vocabulary knowledge is knowledge of words that not only implies definition, but also implies how each word fits into the world. Next definition from Nunan (1999) stated that a vocabulary is more than list of target language words. As a part of the language system, vocabulary intimately interrelated with grammar. In fact, it is possible to device the lexical system of most language into "grammatical word" such as preposition, articles and adverb and so on, and content words. So, based on the explanation above vocabulary is words that have meaning to make a words to be a sentence in order to result a goals in conversation. It also can be said that vocabulary is one component in language that must be taught to the learners, because vocabulary is foundation of language. So, 
when students want to study English, the first action they must be learned vocabulary.

The process of learning English as foreign language is the same with the process when the children learn to speak for the first time. In the teaching and learning process involves language skills namely; listening, speaking, reading, and writing. But all of the skill are nothing without vocabulary. The basic of study English is study about vocabulary. In the teaching and learning process, there are many problem for the teacher and students, such as the students still have limited vocabulary, they were difficult to use and interpret vocabulary. So, they felt afraid to express their idea and opinion. There are many causes of it such as the students were lazy to memorize new vocabulary and they are difficulties of word meaning and word use when they learing vocabulary.

Dealing with the problems above, Dewi Maduratna (2004) who stated that using Make a Match technique in teaching vocabulary is quite success. It is not only effective to lead students feel more interesting and enjoy doing activity in the class, but also it can give the students the opportunities to be active in learning English vocabulary. Nia Utami, Gatot Sutapa, and Dwi Riyanti (2018) also found the effectiveness of using make and match technique, the students were more enthusiastic and paid more attention to the learning activity. Furthermore, from the administered assessment, it showed that the students expand their vocabularies and can understand the meaning when doing written test in the class. As the result, from the students' individual score, it improved in each cycle. Therefore, the researcher recommends teachers to use Make a Match as a vocabulary teaching technique as to help students improve their vocabulary.

Nurul Azizah F (2018) suggested that the process of teaching vocabulary by using make a match technique is effective. Ria Dhatun Nikmah, Rahmad Husein, and Busmin Gurning (2018) investigated that the result of the research showed that Make a Match Technique can improve students' vocabulary. , the result of this research shows that Make a Match technique is a good vocabulary learning technique. It encourages greater self-direction for students. Thus, it is strongly suggested that teachers apply this technique to help improve vocabulary of the students. Compared to those previous researches, there are some similarities and differences between those researches and this present research. The similarities are those three researches investigated about Make a Match technique and vocabulary same with this research, and the differences with all of them researchers is the researcher curious about the Make a Match technique for teaching vocabulary based on gender. The researcher wanted to find out is there significant improvement of using make a match technique on students' vocabulary mastery between male and female gender.

With all this in mind, the researcher put forwards the following research question;

Is there significant improvement of using make a match technique on students' vocabulary mastery? 
Is there significant differences of vocabulary score between male and female gender?

Vocabulary is one of the most important things in learning English. Kamil and Hiebert (2005) state that vocabulary is set of words for which we know the meaning and also that an individual can use when speaking, reading, writing, and listening. In other definition, Richard and Renandya (2002) state that vocabulary is a core component of language proficiency and provides much of the basis for how learners speak, listen, read and write. Hornby (2010) states that vocabulary is the total number of word in a language vocabulary is a list of words with their meaning. Based on the explanation above, it means, when we learn about English, the vocabulary was needed in all of skills that are listening, speaking reading and writing.. In order to communicate well using English language, the students should get an adequate number of words. Vocabulary is component to English language because without sufficient vocabulary students cannot understand what other says. And vocabulary not only learn about the list of words but also what they mean.

According to I.S.P Nation has divided vocabulary into two they are: First, receptive Vocabulary, it is knowing a word involves being able to recognize it when it is heard (what is the sound like?) or when it seen (what does she like?) and having an expectation of what grammatical pattern the word will occurrence. This includes being able to judge if the word form sound right or look right. Second, productive vocabulary: Knowing a word involves being able to pronounce the word, how to write and spell it, how to use it in grammatical pattern along with the word usually collocates with, it also involves not using the word too often it is typically a lawfrequency word, and using it in a suitable subtitle for the word if there any.

There are aspect of vocabulary, as Thornbury (2002) states that there are several vocabulary aspects that important to be learned, they are word classes, word families, word formation, and multi-word unit. In this research, the researcher will be focus on part of word clasess more specific focus on noun and verb. In word classes divide the words into different roles. That word include in grammatical words or function words that are generally prepositions, conjunctions, determiners, and pronoun. Another one is content words that are carry a high information, such as noun, verb, adjective, and adverb.

According to Arifah and Kusumarasdyati (2013), Make a Match is one of the teaching techniques which can be used in co-operative learning. The Make a match technique is a kind of game where students have to find their partner. In other line, Suprijono (2010) clarifies that by using the Make a Match technique teachers can motivate and encourage their students to be more interested and enthusiastic in learning English. In teaching English to junior high school students, teachers can use the Make a Match technique to make teaching-learning easier. It means that make a match technique can helps students to improve students' vocabulary mastery because this technique make students enjoy and interesting to study the materials. According to Agus Suprijono (2009), stated the process in teaching make a match technique, the first teacher has to provide some cards that consist of question complete with the answer but the teacher has to separate the question and 
the answer in different card. Before giving these cards, the teacher has to divide students into two groups. First group is students who bring the question cards and second group is the students who bring the answers card.

Then, the teacher gives time for students who bring the question card to look for pair based on the question in the card. After the time runs out, the students have to with their pair and then mention the question and answer. If their card match, they get the point. After the first session is over, the teacher gives card again to students with different topic until 2 session.

For example :

Q : It is an animal. It has long ears and a short tail. It likes to eat carrot and other

vegetables. It does not walk but it jump. Who Iam?

A : Rabbit

By using this technique, teacher can teach students in pleasing condition because students will find their suitable card with their card in a good atmosphere. It will make students enjoy in mastering material in the textbook and they never feel bored. This technique also make students be active in the class, do not like when the teacher just explain and explain material will make students be passive because only hear what the teacher said.

Descriptive text is one genre that must be mastered by students in learning English. According to Ervina S (2010), descriptive paragraph is a paragraph that describe about person, place, or thing in such a way that the readers can visualize the topic and enter into the writer's experience. Furthermore, Pardiyono (2007) state that description paragraph is a type of written text paragraph, in which has the specific function to describe about object and it has the aim that is giving description of the object to the reader clearly. Based on the explanation above, it means that descriptive text is paragraph that describe a particular person, place or thing in order to help the reader to think or imagine the characteristic or form of the object. Based on the explanation above, it can be concluded that this research aims to find out the effectiveness of make a match technique to improve students' vocabulary based on gender.

\section{METHOD}

To answer the formulated research question, the researcher conducted a quantitative study in the form of pre experimental design (see J. Creswell, 2014; J. W. Creswell, 2012; Terrell, 2012). In this research, the researcher was used pre-test and post test in the experimental class. The design of research can be illustrated as follows:

\section{T1 X T2}

The research was started by collecting the data of students' vocabulary before the treatment. It was collected by pre-test in the first meeting. The second meeting and the third meeting were the implementation of the treatment of using make a 
match technique. And the last meeting, there was a post-test to collect the data on the students' vocabulary after the treatment.

In this research, population is the students of SMP N 3 Pagelaran, grade XIII academic year 2021/2022. There are four classes, XIII.A, XIII.B, XIII.C, XIII.D . The participant of this research will be XIII.C class. There were 25 students in XIII.C class. The data were homogeneous but by using purposive sampling, the researhcer choose XIII.C, because the students has various score. The researcher also found the students still got difficulty in vocabulary.

In order to collect the data for this research, research instruments were needed. The instruments used in this research to collect the data were a pre-test and posttest. The tests considered of 25 questions about verb, noun, word used and the meaning of words used in the lessons.

To answer the research questions, the data was analyzed through the paired sample T-test. The data from pre-test and post-test were analyzed using SPSS 16.0 for windows. This was done to help the researcher for the purpose of interpretation.

\section{FINDINGS AND DISCUSSION}

The results of this research were analyzed on the formulated research questions. Is there significant improvement of using make a match technique on students' vocabulary mastery? After administering students' vocabulary pre-test and post-test, the data were compared to investigated whether there was a significant improvement in the studnets' vocabulary. The result can be seen in Table 1.

Table 1. Mean of pre-test and

post-test of students' vocabulary mastery

\begin{tabular}{|l|l|l|}
\hline Pre-Test & Post-Test & Difference of Mean \\
\hline 61.76 & 83.28 & 21.76 \\
\hline
\end{tabular}

The Table 1 shows that the mean of the pre test was 61.76 and the mean of the post-test was 83.28. The difference of mean was 21.76. Based on the result, there was improvement of students' vocabulary after treatment by using make a match technique. The result must be completed, so the researcher also analyzed to find the $p$ value and $t$ observed through the paired sample T-test.

Table 2. Paired sample test of students' vocabulary mastery

\begin{tabular}{|c|c|c|c|c|c|c|c|c|}
\hline & \multicolumn{5}{|c|}{ Paired Differences } & \multirow[b]{3}{*}{$\mathrm{t}$} & \multirow[b]{3}{*}{$\mathrm{df}$} & \multirow[b]{3}{*}{ Sig. (2-tailed) } \\
\hline & \multirow[b]{2}{*}{ Mean } & \multirow{2}{*}{$\begin{array}{l}\text { Std. } \\
\text { Devi } \\
\text { ation }\end{array}$} & \multirow{2}{*}{$\begin{array}{l}\text { Std. } \\
\text { Error } \\
\text { Mean }\end{array}$} & \multicolumn{2}{|c|}{$\begin{array}{l}95 \% \text { Confidence } \\
\text { Interval of the } \\
\text { Difference }\end{array}$} & & & \\
\hline & & & & Lower & Upper & & & \\
\hline $\begin{array}{c}\text { Pair 1 } \\
\text { Pre Test- } \\
\text { Post Tset }\end{array}$ & -21.520 & 4.254 & .851 & -23.276 & -19.764 & -25.296 & 24 & .000 \\
\hline
\end{tabular}


In Table 2, it can be seen that the $p$ value $(0,000)$ was lower than 0.05 and $t$-observed (25.296) was higher than $t$-table (2.064) at df. (24). It means that there was a significant differences between the students' vocabulary pre-test and post-test scores. It can be concluded that there was improvement in the students' vocabulary mastery after being taught by using make a match technique.

Is there significant differences of vocabulary score between male and female gender?

Based on the second research question, the difference in the students' vocabulary mastery between male and female of post-test was calculated and compared through the paired sample T-test. The result can be seen in Table 3.

Table 3, Paired sample test of students' vocabulary mastery between male and female gender

Paired Samples Test

\begin{tabular}{|c|c|c|c|c|c|c|c|c|}
\hline & \multicolumn{5}{|c|}{ Paired Differences } & \multirow[b]{3}{*}{$\mathrm{t}$} & \multirow[b]{3}{*}{$\mathrm{df}$} & \multirow[b]{3}{*}{ Sig. (2-tailed) } \\
\hline & \multirow[b]{2}{*}{ Mean } & \multirow{2}{*}{$\begin{array}{c}\text { Std. } \\
\text { Devi } \\
\text { ation }\end{array}$} & \multirow{2}{*}{$\begin{array}{c}\text { Std. } \\
\text { Error } \\
\text { Mean }\end{array}$} & \multicolumn{2}{|c|}{$\begin{array}{l}95 \% \text { Confidence Interval } \\
\text { of the Difference }\end{array}$} & & & \\
\hline & & & & Lower & Upper & & & \\
\hline \begin{tabular}{|l|l|} 
Pair 1 & Female - Male
\end{tabular} & .364 & 6.622 & 1.997 & -4.085 & 4.813 & .182 & 10 & .859 \\
\hline
\end{tabular}

Based on Table 3, it can be seen that the $p$ value (.859) was higher than 0.05 and t-observed (.182) was lower than t-table (2.064) at df. (10). It means that there were not a significant differences between the students' vocabulary post-test scores of female and male. It can be concluded that there were not difference in the ability of female and male in improvement vocabulary mastery.

Considering the result obtained from sample T-test, it was found that the $p$ value $(0,000)$ was lower than 0.05 and t-observed $(25.296)$ was higher than $t$-table (2.064). It can inferred that there was improvement of students' vocabulary after treatment by using make a match technique. But, prior to deep reflection on the improvement of the students' vocabulary, the researcher first has to reflect on how the technique actually worked in the process of the implementation in the classroom. According to Huda (2013) that make a match techniques is one of techniques in cooperative learning develiped by Lorna Curran, in this technique the teacher must prepare some card that contain several concept or topics and answer. The purpose of this technique are deepening of materials, cotrolling of materials, education and entertainment. And then according to Suprijono (2010 in Kusumarasdyati 2013) said that by using make a match technique the students will active and enjoying to learning.

So, the implementation of Make a Match Technique, it facilitated the students to find the meaning of new vocabulary by matching the existing cards in their hands and finding their card partner in a short time. Since the teacher allowed them to freely move to match their cards, the students could actively participate in the activity. The cooperation each student happened dynamically, because they work 
together, sharing their thought about the meaning of the words in the cards, and match the cards with the right partner. This technique can also create a joyful learning because it is like a game, and it involves learning media created by the teacher. The students showed their good attention during teaching and learning process of implementation make a match technique in the classroom.

This finding was in line with a study of who found that make a match technique can improve the students' vocabulary mastery . It make students enjoy to study and easily to understand the materials.

\section{CONCLUSION}

The make a match technique can optimally enable the students to improve their vocabulary mastery. The technique gives the good effect in improving the students'vocabulary mastery. It also make students interesting in teaching and learning vocabulary, this technique helps students to understand about material easily. It can be seen from the result of the pre-test and post-test score, there was improvement of pre-test and post test score. While the result of differences score between female and male based on the post test, there were not significant differences of vocabulary score, it means the gender differences do not effect on students' ability to learn vocabulary. So this technique was quite effective and success in teaching vocabulary mastery.

\section{REFERENCES}

A S Hornby. (2010). "Oxford Advanced Learner"s Dictionary of Curren English", English Dicionary (5thed). Oxford:Oxford University Press

Arifah, M., \& Kusumarasdyati. (2013). "The effectiveness of Make a Match Technique for teaching writing descriptive text to the seventh graders of SMPN 1 Karangbinangun Lamongan". UNESA, I(1), 1-8. Retrieved from ejournal.unesa.ac.id/article/3061/58/article.pdf

Azizah, Nurul F. (2018). "The Implementation of Make a Match Technique to Increase Students' Vocabulary Mastery”, Jurnal Edulingua, Vol 5, No. 2, 4647.

Celce, Murcia and Olshtain. (2000). Discourseand Context in Language Teaching. Cambridge: Cambridge University Press

Creswell, J. (2014). Research design: Qualitative, Quantitative, and Mixed Methods Approaches (V. Knight (ed.); Fourth Edi). SAGE Publication.

https:/ / doi.org/10.4135/9781849208956

Creswell, J. W. (2012). Educational research: Planning, conducting, and evaluating quantitative and qualitative research (4th ed). Pearson

Hilbert Elfrida H and Kamil, Michael M. (2005). Teaching and Learning Vocabulary Bringing Research to Practice, (LEA). New Jersey London

Huda, Miftahul. (2013). Model-model Pengajaran dan Pembelajaran. Yogyakarta: Pustaka Pelajar 
Kamil, M and Hiebert, E. (2005). Teaching and Learning Vocabulary. Mahwah: Kawrence Erlbaum Associates.

Maduratna, Dewi. (2004). "The Impact of the Application of Make a Match Technique Towards Students' Vocabulary Mastery." The Second International Conference on Education and Language, 2, p. 290-294.

Nikmah, Ria Dhatun et al. (2018). "The Effectiveness of Make a Match Technique in Teaching Vocabulary." Advances in Social Science, Education and Humanities Research

Richards, Jack C.\&Renandya, W, A. (2002). Methodology in Language Teaching: An Anthology of Current Practice. New York: Cambridge University Press

Suprijono, A. (2010). Cooperative learning: Teori dan aplikasi PAIKEM (2nd Ed.). Yogyakarta:Pustaka Pelajar

Suprijono, A. (2009). Cooperative learning: Theory and Application of Paikem. Surabaya: Library Study.

Stahl, S. (2005). Four problems with teaching word meanings (and what to do to make vocabulary an integral part of instruction). In E. H. Hiebert and M. L. Kamil (Eds), Teaching and learning vocabulary: Bringing research to practice (pp. 95-114). Mahwah, NJ: Lawrence Erlbaum.

Terrell, S. R. (2012). Mixed-Methods Research Methodologies. The Qualitative Report, 17(1), 254-280.

Thornbury, Scott . (2002). How to teach Vocabulary .Essex: Person Educational Limited

Utami, Nia et al. (2018). "Improving Students' Vocabulary through Make a Match Technique," Jurnal Pendidikan dan Pembelajaran Khatulistiwa, Vol 7, No 12, $1-7$. 